Menoufia J. Agric. Biotechnology, Vol. 5 February (2020): 23 - 33

\title{
COMPARATIVE STUDY ON LUPINE AND FENUGREEK SEEDS THAT GROW IN EGYPT
}

\author{
S.A. Elkadousy(1), Samia. M. Khalil(1), Houda A. Fareed(1), \\ and H. M. Mahmoud(2) \\ (1) Biochemistry department, Faculty of Agriculture, Menoufia University \\ (2) Management of snails control in Giza
}

Received: Dec. 1, 2019

Accepted: Dec. 8, 2019

\begin{abstract}
Main chemical composition, bioactive constituents and antioxidant activity of Egyptian lupine and fenugreek seeds were investigated. The obtained results showed that white lupine seeds have higher amount of carbohydrate and ash than that in the other seeds. Meanwhile yellow lupine seeds showed the highest percentage of fibers among all tested seeds, while fenugreek seeds were characterized by large amount of crude protein, oil and moisture comparing with both kinds of lupine seeds.
\end{abstract}

On the other side, analysis of bioactive constituents revealed the presence of total phenolics, total flavonoids as well as saponins in the highest amount in fenugreek seeds, whereas the highest values of alkaloids and tannins were belonged to yellow lupine. It is noteworthy that white lupine exhibited the lowest amounts of all tested bioactive components among all studied seeds.

And finally, in vitro antioxidant activity using two deferent methods, showed a correlation between total phenolics and total flavonoids on one hand and antioxidant activity on the other hand, where it showed the highest values for fenugreek seeds followed by yellow and white lupine seeds respectively.

Key words: lupines (white and yellow) and fenugreek seeds-Alloxan-Diabetic ratsHypoglycemia - Antioxidant enzymes.

\section{INTRODUCTION}

Nutritional value of white and yellow lupine as well as fenugreek seeds was studied by many researchers, and it was found that white lupine seeds contain, carbohydrate $3.27 \%$, protein $35.8 \%$, oil $9.4 \%$, crude fiber $10.6 \%$ (Cowling et al, 1998), and that yellow lupine seeds contain $1.38 \%, 37.9 \%, 33.68 \%$ and $4 \%$, respectively for the same components, while fenugreek seeds presented for such components percentages of $45.2 \%$, $29.3 \%, 7.9 \%$ and $7 \%$, respectively Birhane, (2012)

Meanwhile, studies on bioactive constituents in the tested seeds demonstrated the presence of phenolics, flavonoids, alkaloids, saponins and tannins in varying proportions (Patel and Dhanabal, 2013; Duke, 1992; Kalogeropoulos et al., 2010).

In this context a great number of in vitro methods have been developed to measure the efficiency of natural antioxidants for methanolic extracts of white lupine seeds owing to their content of phytoestrogens such as flavonoids (Adlercreutz, and Mazur, 1997), yellow lupine seeds which have high levels of phenolic compounds mainly tannins and flavonoids (Zia et al., 2001) and fenugreek seeds which their antioxidant property is attributed to their high content of phenolic constituents (Chatterjee et.al., 2009). 


\section{MATERIALS AND METHODS}

1-Plant collection and identification:

The seeds of white lupine (sweet lupine), yellow lupine (bitter lupine) and fenugreek were obtained from research center department of medical and aromatic plants Giza, Egypt; the seeds were identified in horticulture department, faculty of agriculture, Menoufia University.

Seeds samples were washed and airdried for 24 hours, then dried at $50^{\circ} \mathrm{C}$. The dried sample was grinded into fine powder and kept in refrigerator for analysis.

\section{2-Main chemical composition of seeds}

Total nitrogen was determined (dry basis) according to the modified microkjelahl method as described by the association of official Analytical Chemists, A.O.A.C., (2000). The crude protein contents were calculated using the conversion factor 6.25. Total lipids and moisture were determined according to A.O.A.C., (2000). Total carbohydrate were estimated according to the method of Dubois et al., (1956), while crude fiber was determined according to the method illustrated in A.O.A.C., (2008), and finaly ash content was determined by ignition of dried sample at $550^{\circ} \mathrm{C}$ until a constant weight according to ( A.O.A.C., 1990).

\section{3-bioactive constituents in tested seeds}

\section{Determination of hydrolysable tannins (HTs):}

HTs were determined by the method of Cam and Hisil (2010). $1 \mathrm{ml}$ of 10-fold diluted methyl extracts and $5 \mathrm{ml}$ of $2.5 \%$ $\mathrm{KIO}_{3}$ were added into a vial and vortex for $10 \mathrm{sec}$. Optimum absorbance of the red colored mixture was determined at
$550 \mathrm{~nm}$ versus the prepared water blank. Optimum absorbance, defined as the time to gain maximum absorbance value, was determined and tannic acid solutions (100 to $1600 \mathrm{mg} / \mathrm{l}$ ) were used for calibrations.The final results were expressed as mg tannic acid equivalent per g of dry weight (mg TAE/g DW).

\section{Determination of saponins:}

The defatted seeds flours (residue after oil extraction) were kept at room temperature overnight. The next day, 30 $\mathrm{ml}$ methanol was added to the tubes and left on the shaker all night, followed by centrifugation.The second and third extractions by methanol was also carried out. At the end, all supernatants of methanol extracts were pooled and the methanol was evaporated using rotary evaporator. Finally, a yellowish crystal powder of crude saponins was obtained which was determined according to the method of Uematsu et al., (2000).

\section{Determination of alkaloids:}

The plants material $(\mathbf{1 0 0 g})$ were ground and then extracted with methanol for $24 \mathrm{hrs}$. In a continuous extraction (soxhlet) apparatus, the extraction was filtered and methanol was evaporation on a rotary evaporated under vacuum at a temperature of $45^{\circ} \mathrm{C}$ to dryness. A part of this residue was dissolved in $(2 \mathrm{~N}) \mathrm{HCl}$ and then filtered. One $\mathrm{ml}$ of this solution was transferred to a separatory funnel and washed with $10 \mathrm{gm}$ chloroform (3 times). The $\mathrm{pH}$ of this solution was adjusted to neutral with $(0.1 \mathrm{~N}) \mathrm{NaOH}$. Then $5 \mathrm{ml}$ of bromocresol green solution and $5 \mathrm{ml}$ of phosphate buffer (pH 4.7) were added to this solution. The mixture was shaken and the complex formed was extracted with $1,2,3$, and $4 \mathrm{ml}$ chloroform by vigorous shaking. The extracts were collected in a 10-ml volumetric flask and diluted to the 
adjusted volume with chloroform, the absorbance test of the complex in chloroform was measured at $470 \mathrm{~nm}$ against blank and standard solutions according to the method of Fazel et al., (2008).

\section{Determination of total phenolics:}

The amount of total phenolics in the studied extracts was determined with the Folin-Ciocateu reagent. Gallic acid was used as standard and the total phenolics were expressed as $\mathrm{mg}$ gallic acid equivalents (GAE/g dry weight). $10 \mathrm{ml}$ of samples were extracted in methanol, 0.5 $\mathrm{ml}$ of each sample and standard were introduced into test tubes and mixed with $2.5 \mathrm{ml}$ of Folin-Cicalteu reagent diluted to 10 fold and $2 \mathrm{ml}$ of $7.5 \%$ sodium carbonate. The tubes were covered tightly and allowed to stand for $\mathbf{3 0} \mathrm{min}$. at room temperature before the absorbance which was read at $760 \mathrm{~nm}$ spectrometrically Kim et al., (2003).

\section{Determination of total flavonoids:}

The total flavonoids content was determined using the method reported by Djeridane et al., (2006). Briefly, an aliquot of $250 \mu \mathrm{l}$ of each methanolic extract or a standard solution was mixed with $1.25 \mathrm{ml}$ deionized water, followed by $75 \mu \mathrm{l}$ of a $5 \%$ $\mathrm{NaNO}_{2}$ solution after 6 min., $150 \mu \mathrm{l}$ of 10 $\% \mathrm{AlCl}_{3} .6 \mathrm{H}_{2} \mathrm{O}$ solution was added to each mixture, after $5 \mathrm{~min}$. $0.5 \mathrm{ml}$ of $1 \mathrm{M}$ $\mathrm{NaOH}$ was added, and the total volume was adjusted to $3.0 \mathrm{ml}$ with deionized water. Catechin was used as a standard using absorbance at $510 \mathrm{~nm}$ for the measuring which was corrected using a blank, the results were expressed as $\mathrm{mg}$ of catechin equivalents (CE) /g dry weight.

Qualitative and quantitative analysis of phenolics using GC/MS method:
The analysis of plant extracts was carried out using a GC (Agilent Technologies 7890 A) interfaced with a mass-selective detector (MSD, Agilent 7000) equipped with an apolar Agilent HP-5ms (5\%phenyl methyl poly siloxane) capillary column $(30 \mathrm{~m} \times 0.25 \mathrm{~mm}$ i.d. and $0.25 \mathrm{um}$ film thickness) the carrier gas was helium with the linear velocity of $\mathbf{1 . 0}$ $\mathrm{ml} / \mathrm{min}$.

The identification of components was based on comparison of their mass spectra and retention time with those of the authentic compounds and by computer matching with NIST and WILEY library as well as by comparison of the fragmentation pattern of the mass spectral data with those reported in the literature Partricia, et al., (2013).

\section{4-In-vitro antioxidant activity:}

Which was determined by two different methods because of the complex nature of phytochemicals (Chanda and Dave, 2009), in order to evaluate the antioxidant activity capacity of plant materials and these methods include:

\section{4-1 Reducing power assay using potassium ferricyanide:}

It is based on the principle that substances, which have reduction potential, react with potassium ferricyanide $\left(\mathrm{Fe}^{3+}\right)$ to form potassium ferrocyanide $\left(\mathrm{Fe}^{2+}\right)$, which then react with ferric chloride to form ferric-ferrous complex that have an absorption maximum at $700 \mathrm{~nm}$. The reducing power of different extracts was determined according to the method of Ebrahimzadeh et al., (2008), where $2.5 \mathrm{ml}$ of extract $(200 \mu \mathrm{g} / \mathrm{ml})$ in water were mixed with a phosphate buffer $(2.5 \mathrm{ml}$, $0.2 \mathrm{M}, \mathrm{pH} 6.6$ ) and potassium ferricyanide (2.5 $\mathrm{ml}, 1 \%)$. The mixture was incubated 
at $50^{\circ} \mathrm{C}$ for $20 \mathrm{~min}$. A portion $(2.5 \mathrm{ml})$ of trichloroacetic acid (10\%) was added to the mixture to stop the reaction, which was then centrifuged at $\mathbf{3 0 0 0} \mathrm{rpm}$ for 10 min. The upper layer of solution $(2.5 \mathrm{ml})$ was mixed with distilled water $(2.5 \mathrm{ml})$ and $\mathrm{FeCl}_{3}(0.5 \mathrm{ml}, 0.1 \%)$ and the absorbance was measured at $700 \mathrm{~nm}$ against blank. Increased absorbance of the reaction mixture indicated increased reducing power.

\section{4-2 $\quad \beta \beta^{\prime}$-diphenyl- $\alpha$-picrylhydrazyl (DPPH) radical scavenging activity:}

The antioxidant activity of both plant extracts and standard was assessed on the basis of the radical scavenging effect of the stable $\beta \beta^{\prime}$-diphenyl- $\alpha$ picrylhydrazyl (DPPH) by modified method of Braca et al., (2002). The diluted working solutions of the test extracts were prepared in methanol. Ascorbic acid was used as standard. $0.004 \%$ of DPPH was prepared in methanol and $1 \mathrm{ml}$ of this solution was mixed with $1 \mathrm{ml}$ of sample solution $(100 \mu \mathrm{g} / \mathrm{ml})$ and standard solution $(100 \mu \mathrm{g} / \mathrm{ml})$ separately. These solution mixtures were kept in dark for 20 min. and optical density was measured at $517 \mathrm{~nm}$ using spectrophotometer. Methanol $(1 \mathrm{ml})$ with DPPH solution
$(0.004 \%, 1 \mathrm{ml})$ was used as blank. The optical density was recorded and \% inhibition was calculated using the formula given below:

Percent (\%) inhibition of DPPH activity = A - B IA $\times 100$

Where $A=$ optical density of the blank and $B=$ optical density of the sample.

\section{RESULTS AND DISCUSSION}

\section{Main chemical composition of tested seeds :}

Data obtained from Table (1) indicate that white lupine seeds contain, carbohydrate $38.046 \%$, protein $24.476 \%$, oil $7.745 \%$ crude fiber $29.161 \%$, ash $0.452 \%$ and moisture $2.15 \%$ and that yellow lupine seeds contain $38.218 \%$ $22.304 \%, 5.851 \%, 33.143 \%, 0.404 \%$ and $0.08 \%$, respectively for the same aforementioned components, while fenugreek seeds presented for such components percentages of $35.471 \%$, $25.28 \%, 8.489 \%, 30.183 \%, 0.437 \%$ and $0.14 \%$ in the same order.

The results are in accordance with those of Duke., (1992); vats et al., (2003); sujak et al., (2005); Erbas et al., (2005) and Martinez-Villaluenga et al., (2006).

Table (1): Main chemical composition of white lupine, yellow lupine and fenugreek seeds.

\begin{tabular}{|c|c|c|c|c|}
\hline \multirow{2}{*}{$\begin{array}{c}\text { Chemical } \\
\text { composition }\end{array}$} & \multicolumn{3}{|c|}{ Type of seeds } \\
\cline { 2 - 4 } & $\begin{array}{c}\text { White lupine } \\
\%\end{array}$ & $\begin{array}{c}\text { Yellow lupine } \\
\%\end{array}$ & $\begin{array}{c}\text { Fenugreek } \\
\%\end{array}$ & \\
\hline Total carbohydrate & 38.046 & 38.218 & 35.471 & \\
\hline Crude protein & 24.476 & 22.304 & 25.28 & \multirow{2}{*}{ 尔 } \\
\hline Oil & 7.745 & 5.851 & 8.489 & \multirow{2}{*}{} \\
\hline Crude fiber & 29.161 & 33.143 & 30.183 \\
\hline Ash & 0.452 & 0.404 & 0.437 & \\
\hline Moisture & 0.12 & 0.08 & 0.14 & \\
\hline
\end{tabular}




\section{Bioactive constituents in tested seeds}

The obtained results in Table (2) showed that alkaloids and tannins were in high content in yellow lupine (2.798 and $1.523 \mathrm{mg} / 100 \mathrm{gm} \mathrm{dw}$ ), followed by fenugreek (1.861 and $1.05 \mathrm{mg} / 100 \mathrm{gm}$ dw), while the minor contents were for white lupine (1.352 and $0.596 \mathrm{mg} / 100 \mathrm{gm}$ $d w)$. For saponins, it was found that fenugreek recorded the highest value (5.5 $\mathrm{mg} / 100 \mathrm{gm} \mathrm{dw}$ ) and thereafter yellow lupine (4.8 $\mathrm{mg} / 100 \mathrm{gm} \mathrm{dw})$, whereas white lupine showed the lowest value (3.5 $\mathrm{mg} / 100 \mathrm{gm} \mathrm{dw}$ ).

The results are in the same line with those described by Zia et al., (2001); Schryver, (2002); Vats et al, (2003) and Siger et al., (2012).

On the other hand, date indicate that fenugreek seeds have higher percentages of both total phenolics and flavonoids $\quad(0.848 \%$ and $\quad 0.05 \%$, respectively) than that in lupine seeds. In respect to lupine seeds, it was found that yellow lupine seeds, showed high amount of total phenolics and flavonoids $(0.732 \%$ and $0.021 \%)$ comparing, with that in white lupine seeds $(0.371 \%$ and $0.017 \%$. Theses results are in parallel with those obtained by Rao et al, (1996); Skaltsa, and petropoulos (2002); Lu, et al., (2008) and Siger, et al., (2012).

In connection with the above, it was found that quantitative analysis of phenolic compounds as shown in Table
(3), exhibited the presence of 25 of phenolic compounds in white lupine seeds and 23 ones only in both yellow lupine and fenugreek seeds and that 5.7.3.4-tetrahydroxy flavone represent the main phenolic compound in white lupine and fenugreek seeds $\mathbf{( 7 5 . 1 9 \%}$ and $62.51 \%$, respectively), while it recorded $6.45 \%$ only in yellow lupine seeds.

On the other hand, 4-metylcatechol was the principle component in yellow seeds where it amounted $13.94 \%$ comparing with $3.44 \%$ and 6.98 for white lupine and fenugreek seed, respectively.

Theses results agree with those of Ricardo-Dasilva, et al., 1993; Naidu et al., 2011 and Siger et al., (2012).

Relating to phenolic compounds, antioxidant activity was carried out using two different methods as mentioned earlier. Both of them showed that fenugreek seeds were the highest (Table 4), where their reducing power was 56.225 while antioxidant activity was 82 by the second method followed by yellow lupine where their values in the two methods were 51.4 and 65 respectively and lastly white lupine which showed the lowest percentages in both two methods where they recorded 41.015 and $48 \%$ in the same order.

These results are compatible with those reported by Dixit et al., (2005) and Chanda and Dave (2009).

Table (2): Bioactive constituents in white lupine, yellow lupine and fenugreek seeds.

\begin{tabular}{|l|c|c|c|c|}
\hline \multirow{2}{*}{$\begin{array}{c}\text { Bioactive } \\
\text { phytochemicals } \\
\text { compounds }\end{array}$} & \multicolumn{4}{c|}{ Type of seeds } \\
\cline { 2 - 4 } & White lupine & Yellow lupine & Fenugreek & \multirow{2}{*}{ units } \\
\hline Alkaloids & 1.352 & 2.798 & 1.861 & $\mathrm{mg} / 100 \mathrm{~g} \mathrm{dw}$ \\
\hline Saponins & 3.5 & 4.8 & 5.5 & \\
\hline Tannins & 0.596 & 1.523 & 1.05 & \\
\hline Total Phenolics & 0.371 & 0.732 & 0.848 & \multirow{2}{*}{$\mathrm{g} / 100 \mathrm{~g} \mathrm{dw}$} \\
\hline Total Flavonoids & 0.017 & 0.021 & 0.05 & \\
\hline
\end{tabular}


S.A. Elkadousy, et al.,

Table (3): The phenolic compounds (\%) in methanolic extract of white lupine seeds using GC/MS.

\begin{tabular}{|c|c|c|c|}
\hline NO & $\mathrm{RT}(\min )$ & Area sum \% & Compounds \\
\hline 1 & 3.424 & 3.44 & 4-Methylcatechol \\
\hline 2 & 4.791 & 1.04 & 4-Methoxycinnamic acid \\
\hline 3 & 6.283 & 0.79 & Sinapyl alcohol \\
\hline 4 & 6.283 & 0.77 & Caffeic acid \\
\hline 5 & 6.706 & 1.05 & 4-Hydroxybenzoic acid \\
\hline 6 & 7.166 & 0.76 & Scopoletin \\
\hline 7 & 7.287 & 1.705 & 6-Monohydroxyflavone \\
\hline 8 & 7.910 & 0.85 & 2-Methoxy-5-methylphenol \\
\hline 9 & 8.023 & 0.76 & Neo dihyrocarveol \\
\hline 10 & 8.295 & 0.96 & Fisetin \\
\hline 11 & 8.717 & 2.16 & Quercetin 3,4,7 trimethyl ether \\
\hline 12 & 9.700 & 1.03 & Methyl salicylate \\
\hline 13 & 10.557 & 0.77 & 2-Allyl-p-cresol \\
\hline 14 & 11.937 & 0.78 & Apigenin-8-c-glucoside \\
\hline 15 & 12.685 & 1.11 & 2,4-Dihydroxybenzoic \\
\hline 16 & 12.894 & 1.715 & Juniper camphor \\
\hline 17 & 15.679 & 0.91 & Cyanidincation \\
\hline 18 & 15.867 & 75.19 & $5,7,3^{`}, 4^{\prime}, T^{\prime}$ trahydroxyflavone \\
\hline 19 & 16.662 & 0.97 & Probucol \\
\hline 20 & 17.138 & 0.89 & Zearalenone \\
\hline 21 & 17.355 & 0.83 & Enterodiol \\
\hline 22 & 19.120 & 0.97 & Cannabinol \\
\hline 23 & 21.370 & 1.11 & 4-Tert-octyl-o-cresol \\
\hline 24 & 22,783 & 1.33 & 3,5,7-Trimethoxyflavone \\
\hline 25 & 23.933 & 0.77 & Hydroquinone \\
\hline
\end{tabular}


Comparative study on lupine and fenugreek seeds that grow in Egypt

Table (3): Cont.

\begin{tabular}{|c|c|c|c|}
\hline NO & $\mathrm{RT}(\mathrm{min})$ & Area sun\% & Compounds \\
\hline 1 & 3.424 & 13.94 & 4-Methylcatechol \\
\hline 2 & 4.791 & 2.36 & 4-Methoxycinnamic acid \\
\hline 3 & 6.283 & 2.66 & Caffeic acid \\
\hline 4 & 7.166 & 6.89 & Scopoletin \\
\hline 5 & 7.287 & 2.62 & 6-Monohydroxyflavone \\
\hline 6 & 7.910 & 2.96 & 2-Methoxy-5-methylphenol \\
\hline 7 & 8.023 & 2.33 & Neo dihyrocarveol \\
\hline 8 & 8.295 & 2.4 & Fisetin \\
\hline 9 & 8.717 & 2.18 & Quercetin 3,4,7-trimethyl ether \\
\hline 10 & 9.700 & 7.76 & Methyl salicylate \\
\hline 11 & 10.557 & 2.76 & 2-Allyl-p-cresol \\
\hline 12 & 10.845 & 2.31 & Tetramethyl phenol \\
\hline 13 & 11.937 & 2.72 & Apigenin-8-c-glucoside \\
\hline 14 & 12.685 & 1.89 & 2,4-Dihydroxybenzoic acid \\
\hline 15 & 12.894 & 1.53 & Juniper camphor \\
\hline 16 & 15.679 & 4.03 & Cyanidin cation \\
\hline 17 & 15.867 & 6.45 & $5,7,3^{`}, 4^{`}$-Tetrahydroxyflavone \\
\hline 18 & 16.662 & 5.8 & Probucol \\
\hline 19 & 17.138 & 3.54 & Zearalenone \\
\hline 20 & 17.355 & 5.51 & Enterodiol \\
\hline 21 & 19.120 & 4.72 & Cannabinol \\
\hline 22 & 21.370 & 4.74 & 4-Tert-octyl-o-cresol \\
\hline 23 & 22,783 & 7.91 & 3,5,7-Trimethoxy flavone \\
\hline
\end{tabular}


S.A. Elkadousy, et al.,

Table (3): Cont.

\begin{tabular}{|c|c|c|c|}
\hline NO & $\mathrm{RT}(\mathrm{min})$ & Area sum\% & Compounds \\
\hline 1 & 3.424 & 6.98 & 4-Methylcatechol \\
\hline 2 & 4.791 & 1.23 & 4-Methoxycinnamic acid \\
\hline 3 & 6.283 & 0.76 & Caffeic acid \\
\hline 4 & 7.166 & 1.04 & Scopoletin \\
\hline 5 & 7.287 & 0.85 & 6-Monohydroxyflavone \\
\hline 7 & 8.023 & 0.66 & Neo dihyrocarveol \\
\hline 8 & 8.295 & 0.76 & Fisetin \\
\hline 9 & 8.717 & 0.68 & Quercetin 3,4,7-trimethyl ether \\
\hline 10 & 9.700 & 1.7 & Methyl salicylate \\
\hline 11 & 10.557 & 0.92 & 2-Allyl-p-cresol \\
\hline 12 & 11.937 & 0.78 & Apigenin-8-c-glucoside \\
\hline 13 & 12.685 & 1.12 & 2,4-Dihydroxybenzoic acid \\
\hline 14 & 12.894 & 1.38 & Juniper camphor \\
\hline 15 & 15.679 & 2.29 & Cyanidin cation \\
\hline 16 & 15.867 & 62.51 & $5,7,3^{\prime}, 4^{\prime}$, Tetrahydroxyflavone \\
\hline 17 & 16.662 & 4.57 & Probucol \\
\hline 18 & 17.138 & 1.83 & Zearalenone \\
\hline 19 & 17.355 & 1.62 & Enterodiol \\
\hline 20 & 19.120 & 0.69 & Cannabinol \\
\hline 21 & 21.370 & 1.9 & 4-Tert-octyl-o-cresol \\
\hline 22 & 22,783 & 2.96 & 3,5,7-Trimethoxy flavone \\
\hline 23 & 23.933 & 2.77 & Hydroquinone \\
\hline
\end{tabular}

Table (4): In-vitro antioxidant activity of tested seeds extracts.

\begin{tabular}{|l|c|c|c|}
\hline \multirow{2}{*}{ Methods of antioxidant activity } & \multicolumn{3}{|c|}{ Type of seeds } \\
\cline { 2 - 4 } & White lupine & Yellow lupine & Fenugreek \\
\hline Reducing power & 41.015 & 51.40 & 56.525 \\
\hline DPPH radical scavenging activity & 48.0 & 65.0 & 82.0 \\
\hline
\end{tabular}




\section{REFERENCES}

A.O.A.C. (1990). Official methods of analysis of the Association of Official Analytical Chemists, $15^{\text {th }}$ ed. Sec. 985.29. The Association: Washingtones, DC USA.

A.O.A.C. (2000). Official method of analysis (vol. II $17^{\text {th }}$ edition) of A.O.A.C International, Association of Official Analytical Chemists, Washington DC, USA

A.O.A.C. (2008). Official methods of analysis 16th ed. Association of Official Agriculture, Washington DC. Analytical Chemists International Arligton, Virginia,U.S.A.

Adlercreutz, H. and Mazur, W. (1997). Phytoestrogens and western diseases. Ann Med 29 95-120.

Birhane, G. (2012). Effect of processing on phytochemicals and nutrients composition of fenugreek (Trigonella foenum-graecum L.), and development of value added products (Doctoral dissertation, AAU).

Braca, A., C. Sortino and M. Politi (2002). Antioxidant activity of flavonoids from Licania licaniaeflora. J. Ethnopharmacol 79: 379- 381

Cam, M. and Y. Hisil (2010). Pressurised water extraction of polyphenols from pomegranate peels. Food Chem. 123(3): 878-885

Chanda, S. and R. Dave (2009). In vitro models for antioxidant activity evaluation and some medicinal plants possessing antioxidant properties: An overview. African Journal of Microbiology Research., 3(13): 981996.

Chatterjee, S., P.S. Variyar and A. Sharma (2009). Stability of lipid constituents in radiation processed fenugreek seeds and turmeric: role of phenolic antioxidants. J.Agric.Food Chem.57: 9226-9233.
Cowling, W.A., B.J. Buirchell and M.E. Tapia (1998). Lupine (Lupinus. L), promating The use of underutilized nd neglected crops.23 (Institute of plant geneices and crop plants research, gasterslcbem/International Plant Genetic Resource Institute: rome,Italy)

Dixit, P., S. Ghaskadbi, H. Mohan and T. P. Devasagayam (2005). Antioxidant properties of germinated fenugreek seeds. Phytother. Res. 19: 977-983.

Djeridane, A., M. Yousfi, B. Nadjemi, D. Boutassouna, P. Stocker and N. Vidal (2006). Antioxidant activity of some Algerian medicinal plants extracts containing phenolic compounds. Food Chem. 97(4):654-660.

Dubois, M., F. Smith, K.A. Gilles, J.K. Hammilton and P.A. Robers (1956). Colorimetric method to determination of sugars and related substances. Anal.Chem. 28(3): 350-356.

Duke, J. (1992). Handbook of phytochemical constituents of GRAS herbs and other economic plants. Boca Raton, FL. CRC Press. PP: 344, 481.

Ebrahimzadeh, M.A., F. Pourmorad and S. Hafezi (2008). Antioxidant activities of Iranian Corn Silk. Turk. J. Biol. 32: 4349.

Erbas, M., M. Certel and M.K. Uslu (2005). Some chemical properties of white lupin seeds (Lupinus albus L.). Food Chemistry, 89: 341-345.

Fazel, S., M. Hamidreza, G. Rouhollah and V. Mohammadreza (2008). Spectrophotometric determination of total alkaloids in some Iranian medicinal plants, Thai J. Pharm. Sci. 32 17-20

Kalogeropoulos, N., A. Chiou, M. loannou, V.T. Karathanos, M. Hassapidou and N.K. Andrikopoulos (2010). Nutritional evaluation and bioactive microconstituents 
(phytosterols, tocopherols, polyphenols, triterpenic acids) in cooked dry legumes usually consumed in the Mediterranean countries. Food Chemistry 121, 682690.

Kim, D., S. Jeong and C. Lee (2003). Antioxidant capacity of phenolic phytochemicals from various cultivars of plums. Food Chem. 81, 321-326.

Lu, F.R., L. Shen, Y. Qin, L. Gao, H. Li and Y. Dai (2008). Clinical observation on Trigonella foenum-graecum $L$. Total saponins in combination with sulfonylureas in the treatment of type 2 diabetes mellitus. Chinese Journal of Integrative Medicine, 14, pp.56-60.

Martinez-Villaluenga, C., J. Frias and C. Vidal-Valverde (2006). Functional lupin seeds (Lupinus albus $L$. and Lupinus luteus L.) after extraction of $\alpha$ galactosides. Food Chemistry, 98: 291-299.

Naidu, M., B. N. Shyamala, N.J. Pura, G. Sulochanamma and P. Srinivas (2011). Chemical composition and antioxidant activity of the husk and endosperm of fenugreek seeds. Food. Sci. Technol. 44: 451-456.

Partricia, M., M. Santanal, J. Miranda and P. Abreu (2013). Gas chromatographymass spectrometry study. International journal of organic chemistry, 3,105-109

Patel, D.K. and S.P. Dhanabal (2013). Development and optimization of bioanalytical parameters for the standardization of Trigonella foenumgraecum. J. Acut. Disease. 137-139.

Rao, P.U., B. Sesikeran, PS. Rao, A.N. Naidu, V.V. Rao and E.P. Ramacjandran (1996). Short term nutritional and safety evaluation of fenugreek. Nutr. Res. 16: 1495-1505.
Ricardo-dasilva, J.M., O. Laureano and M.L. Beirao-dacosta (1993). Total phenol and proanthocyanidin evaluation of Lupinus species. In: International Lupin Conference Evora, Portugal. (Edited by Martins J.M. and Beirao da Costa M.L.). Pp. 250-254. Lisbon: ISA Press.

Schryver, T. (2002). Fenugreek. Total Health 24:42-44.

Siger, A., J. Czubinski, P. Kachlicki, K. Dwiecki, E. Lampart-Szczapa and M. Nogala-Kalucka (2012). Antioxidant activity and phenolic content in three lupin species. Journal of Food Composition and Analysis, 25, 190197.

Skaltsa, H. and G.A. Petropoulos (2002). Chemical constituents, in Fenugreek the genus Trigonella, Taylor and Francis, London and New York. pp. 132-161

Sujak, A., A. Kotlarz and A. Strobel (2005). Compositional and nutritional evaluation of several lupine seeds. Science Direct, 98, pp. 711-719,

Uematsu, Y., K. Hirata and K. Saito (2000). Spectrophotometric determination of saponin in Yucca extract used as food additive. J. AOAC Int. 83: 1451-1454.

Vats, V., S.P. Yadav and J.K. Grover (2003). Effect of Trigonella foenumgraecum on glycogen content of tissues and the key enzymes of carbohydrate metabolism. Journal of Ethnopharmacology 85: 237-242.

Zia, T., S.N. Hasnain and S.K. Hasan (2001). Evaluation of the oral hypoglycemic effect of Trigonella foenum graecum L. (methi) in normal mice. J. Ethnopharmacol 75: 191-195. 


\author{
دراسه مقارنه علي بذور الترمس والحلبه المزروعه في مصر \\ سمير عبد القادر القدوسي(')، ساميه محمود خليل(')، هدى أحمد فربد(')،
}

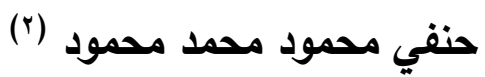

(1) قسم الكيمياء الحيويه كليه الزراعه جامعة المنوفيه

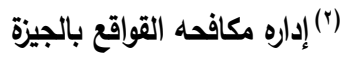

الملخص العربي

تمت دراسـه التركيب الكيميائي لبذور الترمس والحلبه من ناحية المكونات الأساسية وكذا المركبات النثطه بلأضافه الي

النشاط المضاد للأكسده لمستخلصات هذه البذور

وقد أظهرت النتائج التحصل عليها ما يلي :

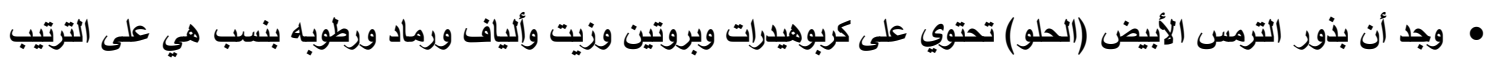

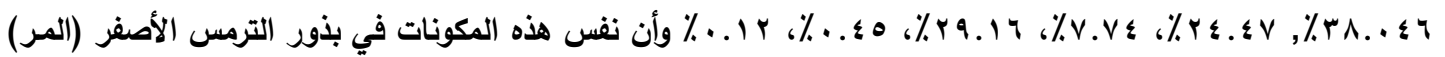

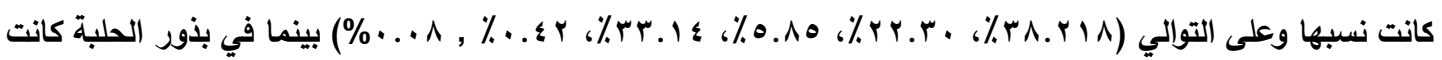

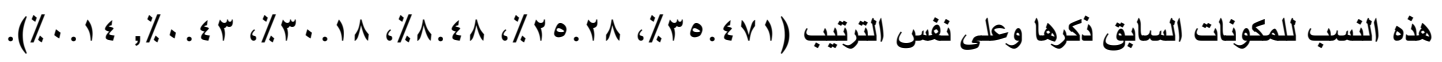

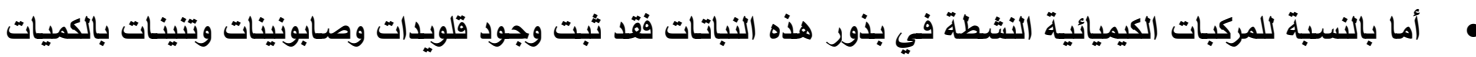

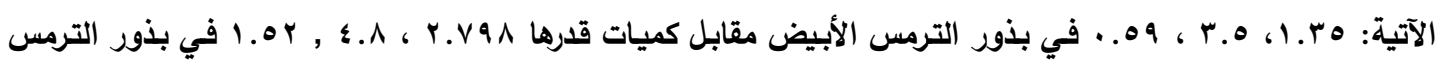

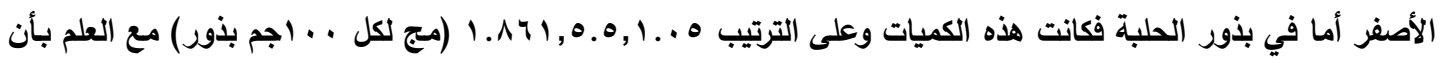

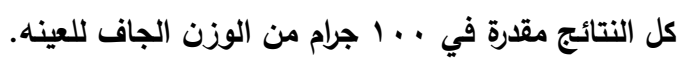

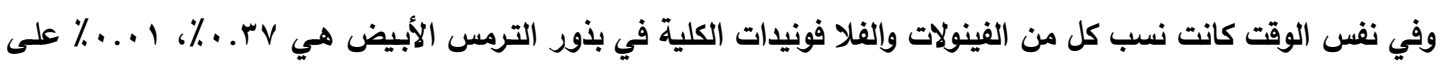

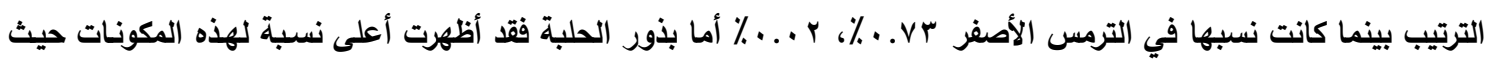

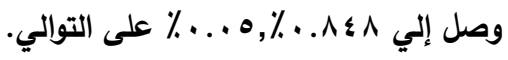

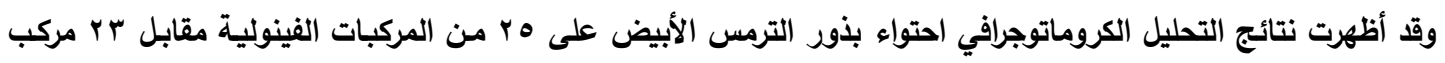

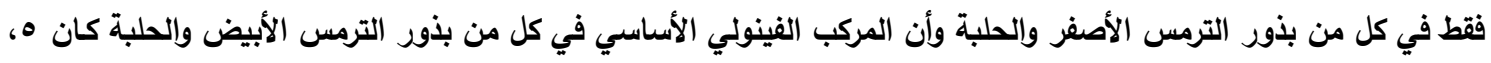

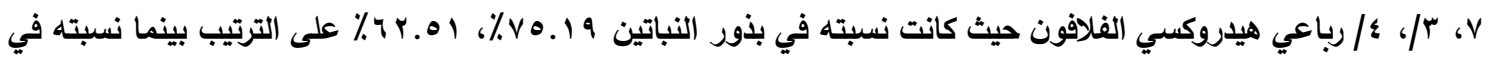

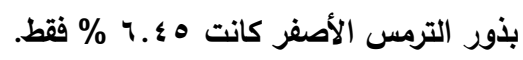

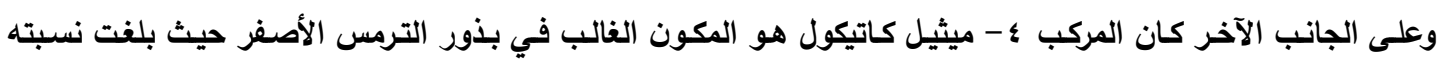

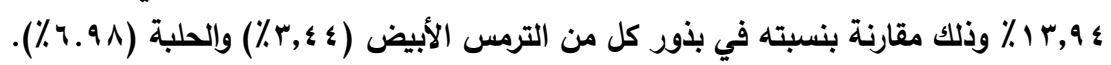

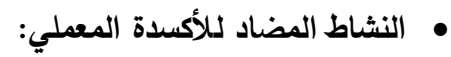

وقد تم بطريقتين (طريقه قياس القدره ألأختزاليه وطريقه إزالهه الثق الحره DPPH ) وقد أظهرت كلتا الطريقتين أن بذور

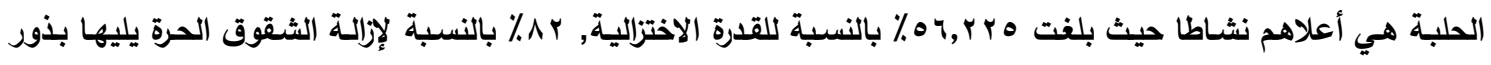

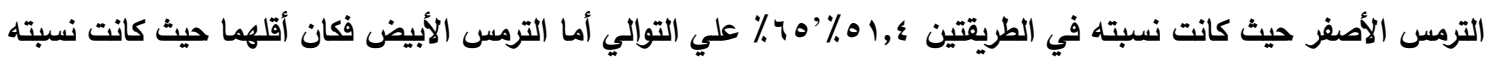

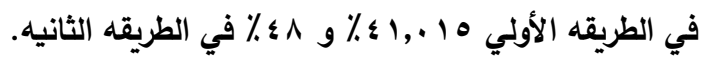
السادة المحكمين

كلية العوم - جامعة المنوفية أ.د/ صلاح محمد القوصـى العين أ.د/ صلاح منصور عبدالجواد كلية الزراعة - جامعة المنوفية 